\title{
Seasonal distribution of harp seals (Phoca groenlandica) in the Barents Sea
}

\author{
TORE HAUG, KJELL, TORMOD NILSSEN, NILS ØIEN and VLADIMIR POTELOV!
}

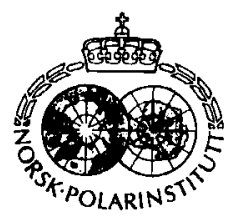

Haug, T., Nilssen, K. T., Øien, N. \& Potelov, V. 1994: Seasonal distribution of harp seals (Phoca groenlandica) in the Barents Sea. Polar Research 13(2), 163-172.

The distributional patterns of Barents Sea harp seals (Phoca groenlandica) throughout the year are presented based on existing literature and recent Norwegian and Russian field observations. The harp seals breed in February-March in the White Sea. Moulting occurs during April to June in the White Sea and southern Barents Sea. Feeding behaviour is closely related to the configuration and localisation of the drifting sea-ice during summer and autumn (June-October) when the seals follow the receding ice edge, retiring gradually northwards and northeastwards in the Barents Sea. The southward movement of the population in autumn probably takes place in November prior to the advance of the ice edge, and is likely related to food-search. Apparently, most Barents Sea harp seals seems to concentrate at the southern end of their range in winter and spring.

T. Haug and K. T. Nilssen. Norwegian Institute of Fisheries and Aquaculture, Breivika, P.O. Box 25ll, N-9002 Troms $₫$, Norway; N. Øien, Inssitute of Marine Research, P.O. Box 1870 Nordnes. N-5024 Bergen, Norway; V. Potelov, Polar Research Institute of Marine Fisheries and Oceanography (PINRO), 6 Knipovich Street, 183763, Murmansk, Russia.

\section{Introduction}

Three stocks of harp seals (Phoca groenlandica) inhabit the North Atlantic Ocean, whelping respectively at Newfoundland and in the Gulf of St. Lawrence (the Northwest Atlantic stock), off the east coast of Greenland (the Greenland Sea stock), and in the White Sea (the Barents Sea stock) (Sergeant 1991). All three stocks have been subjected to exploitation, and have been managed separately. Recent studies of stock identities based on studies of allozymes have revealed significant differences between the Northwest Atlantic stock on one side and Greenland Sea and the Barents Sea stocks on the other, while no evidence of differences between the two latter was observed (Meisfjord \& Nævdal in press). Most likely, some mixing of these two stocks occurs. It has been hypothesised that harp seals from the Barents Sea and from the Greenland Sea intermix during the summer in waters off Svalbard (Sivertsen 1941). Such mixing between these two breeding stocks on feeding grounds is confirmed from more recent tagging experiments (Øien \& Øritsland 1991).

In the Barents Sea, the harp seal is the most abundant seal species. Harp seals are traditionally

\footnotetext{
${ }^{1}$ Authorship equal.
}

caught by Soviet/Russian and Norwegian sealers in March-May in the East Ice, i.e., the pack-ice areas in the White Sea and southeastern Barents Sea (Wollebæk 1907; Iversen 1927; Sivertsen 1941; Jakovenko 1967). Norwegian estimates suggested a total stock size in 1978 of ca. 800,000 seals producing approximately 170,000 pups annually and increasing at an annual rate of about $5 \%$ at that time (Benjaminsen 1979). In 1980, Soviet aerial surveys confirmed a pup production similar to the Norwegian 1978 estimates (Anon. 1992). However, later Russian surveys and Russian and Norwegian age composition data indicated that a reduction may have prevailed in recruitment after 1985 (Anon. 1992, 1994; Kjellqwist et al. in press). Large bycatches of harp seals in gill-net fisheries during the harp seal invasions in Norwegian coastal waters through 1986-1988 (Haug et al. 1991) may have influenced the 1986-1988 cohorts, which show a consistent low representation in Norwegian catches of moulting harp seals in the East Ice in recent years (Kjellqwist et al. in press). Recruitment of one year old seals to the moulting stock did not improve significantly until 1992 (Kjellqwist et al. in press), and Russian aerial surveys, conducted in 1991, resulted in an estimate of 141,600 breeding females in the White Sea that year (Anon. 1994). 
Although there are uncertainties connected to the present abundance of the Barents Sea harp seals stock, there is no doubt that this numerous species is an important predator. Field studies designed to identify the composition and quantity of prey consumed and to evaluate the ecological role of the Barents Sea harp seals are now in progress (Nilssen et al. 1991, 1992, 1994, in press). The intention is to include the species into a multispecies assessment model (MULTSPEC) for the Barents Sea (see Bogstad \& Tjelmeland 1990).

Knowledge of the distribution of the harp seal stock is necessary to reveal its role in the ecosystem. By combining data on abundance and distribution, knowledge of energy requirements of individuals, and geographical and seasonal variation in diet and its energy content, it is possible to perform an evaluation of the impact of harp seals on commercially important fish species (and also the impact of fisheries on seals). The present study summarises current knowledge of the migrational patterns and the seasonal distribution of harp seals in the Barents Sea and adjacent waters, based mainly on recent Norwegian and Russian field observations. Additionally, information from available literature on the seasonal distribution of Barents Sea harp seals has been consulted (Wollebæk 1907; Smirnov 1924; Iversen 1927; Čapskij 1938, 1961; Sivertsen 1941; Popov 1970).

\section{Materials and methods}

Information on incidental sightings of harp seals since 1968 in the Norwegian and Barents Seas was extracted from a database at the Institute of Marine Research (IMR), Bergen, comprising data received from IMR research vessels, reports from Norwegian fishing vessels, reports from Norwegian coast guard vessels and reports from Russian research vessels. These reports include observation date, position and in some cases also approximate herd size and comments on activity and behaviour.

In addition to these incidental sightings, harp seals distribution data were also available from Norwegian and Russian surveys where all observed marine mammals were recorded. Information from these surveys includes observation date, position and approximate number of harp seals observed.
Norwegian line transect surveys, designed to estimate minke whale (Balaenoptera acutorostrata) abundance, were conducted in the North, Norwegian and Barents seas during the summer (July-August) in 1987, 1988 and 1989 (see Øien 1989, 1990, 1991). In 1992 (July-August) and 1993 (April-May, June-July, August-September) Norwegian scientific surveys designed to catch minke whales along predetermined line transects were conducted in five subareas extending from Lofoten at the Norwegian coast in the south, along the Kola coast in the east, around Bjørnøya and at the western coast of Spitsbergen in the north (Haug 1993; Haug et al. 1994, in press). All marine mammals observed, including harp seals, were recorded during each of these surveys.

During Norwegian ecological harp seals investigations conducted at different parts of the year (Nilssen et al. 1991, 1992, 1994, in press), all harp seals observations were recorded. Surveys were carried out in February 1993 in the drift ice in the southeastern Barents Sea, in March-April 1992 in Varangerfjord, North Norway, in June 1991 in open waters and along the fringe of the pack-ice between Novaja Zemlja and Hopen, in September 1990 and 1991 and in October 1992 in the pack-ice belt between Svalbard and Franz Josef Land.

In December-January 1965/1966 and 1966/ 1967 , in June 1965, in July 1960, 1965 and 1992, in September-October 1967, in November 1987 and in December 1960 Russian shipboard surveys were carried out to explore the distribution of seals (including harp seals) and polar bears (Ursus maritimus) from the White Sea in the south, along coasts and the fringe of the pack ice in the Barents Sea and in the Kara Sea (along the eastern coast of Novaja Zemlja). In July 1983, in August 1981 and 1983, in September 1983 and in October 1987, Russian aerial surveys were carried out in the Barents Sea, covering large areas from the Kola coast in the south to the fringe of the pack ice in the north by flying transects in order to explore the distribution of seals (including harp seals) and polar bears.

Each harp seal observation given in Fig. 1 gives no information about the numbers of animals observed and therefore an observation might represent a single seal or a group of seals. Due to the gregarious nature of harp seals, the latter is the more usual, in some cases with groups of several thousand seals. This gregarious occur- 
rence is very characteristic of the species, and makes misinterpretations with other seal species rather unlikely. Abundance estimates and the exact distribution of harp seals cannot be given based on the present observations. First, because the surveys do not cover the entire Barents Sea area simultaneously at any of the given periods. Second, because the sighting effort varies between time periods and areas and in the case of incidental sightings, is not quantifiable. The present study can only give the trends in distribution and annual migrational patterns.

\section{Results}

\section{January-February}

Very few incidental sightings of harp seals are available from January to February. This is partly due to the restricted period of daylight. However, research surveys conducted off the Kola coast and in the southeastern parts of the Barents Sea (northeast of Cape Kanin) and in the Pechora Sea in 1966, 1967 (Russian) and 1993 (Norwegian) yielded the presence of considerable numbers of harp seals in these areas (Fig. 1). During the ecological studies in February 1993 approximately $75 \%$ of the captured harp seals were subadults (Nilssen et al. 1994). Only a few stragglers were recorded on the Norwegian coast during this period.

\section{March-April}

In March and April, harp seals were seen northwest of the mouth of the White Sea, in Varangerfjord on the Norwegian coast, to the east of Bjørnøya and off the western coast of Spitsbergen (Fig. 1).

\section{May}

In May almost all harp seals were seen in the area between the coast of North Norway and Spitsbergen (Fig. 1).

\section{June-July}

In June and July, harp seals were seen in open and pack-ice waters from Novaja Zemlja to the eastern coast of North Norway, along the packice belt in the north and along the western coast of Spitsbergen (Fig. 1). Occurrence in June of large numbers of harp seals in their latest stages of moulting along the edge of the drift ice in the central Barents Sea southeast of Hopen (mainly west of $40^{\circ} \mathrm{E}$ ) was verified during a Norwegian harp seal survey in mid-June 1991 (Nilssen et al. 1992).

Particularly many Norwegian observations are available from July, mainly due to enhanced effort caused by the extensive minke whale surveys in 1987-1989 and 1992-1993 (Øien 1989, 1990, 1991; Haug et al. 1994, in press). The 1989 minke whale sighting survey had the most complete coverage of the Barents Sea area (Øien 1991), and harp seals were seen along the edge of the ice east of Svalbard and to a considerable extent also pelagically in the central and southeastern Barents Sea. Russian observations made during an aerial survey in 1983 and a research vessel survey in 1991 confirm the pelagic occurrence of harp seals to the west of Spitsbergen, and also the occurrence of considerable numbers of animals occurring on the ice between Bjørnøya and Hopen.

\section{August-September}

In August and September, the distribution of harp seals seems to depend very much on the localisation of the pack-ice edge. Russian observations made during aerial surveys with substantial coverage in 1981 and 1983 revealed harp seals confined to the pack-ice belt east of Bjørnøya and Hopen in the central part of the Barents Sea both in August and September (Fig. 1). The August observations are supported by Norwegian observations which also include harp seals observed in open waters and in the Franz Josef Land archipelago (Fig. 1). During Norwegian field studies of harp seals ecology in the Barents Sea in September 1990 and 1991, it was observed that the seals were confined to the northernmost parts of this ocean (between Svalbard and Franz Josef Land at approximately $78^{\circ}-80^{\circ} \mathrm{N}$ ), and always close to - also to some extent within the pack-ice belt (Fig. 1). During minke whale investigations in 1993, some harp seals were also seen west of Spitsbergen.

\section{October}

The majority of harp seal observations from October were located between the $76^{\circ} \mathrm{N}$ and the 

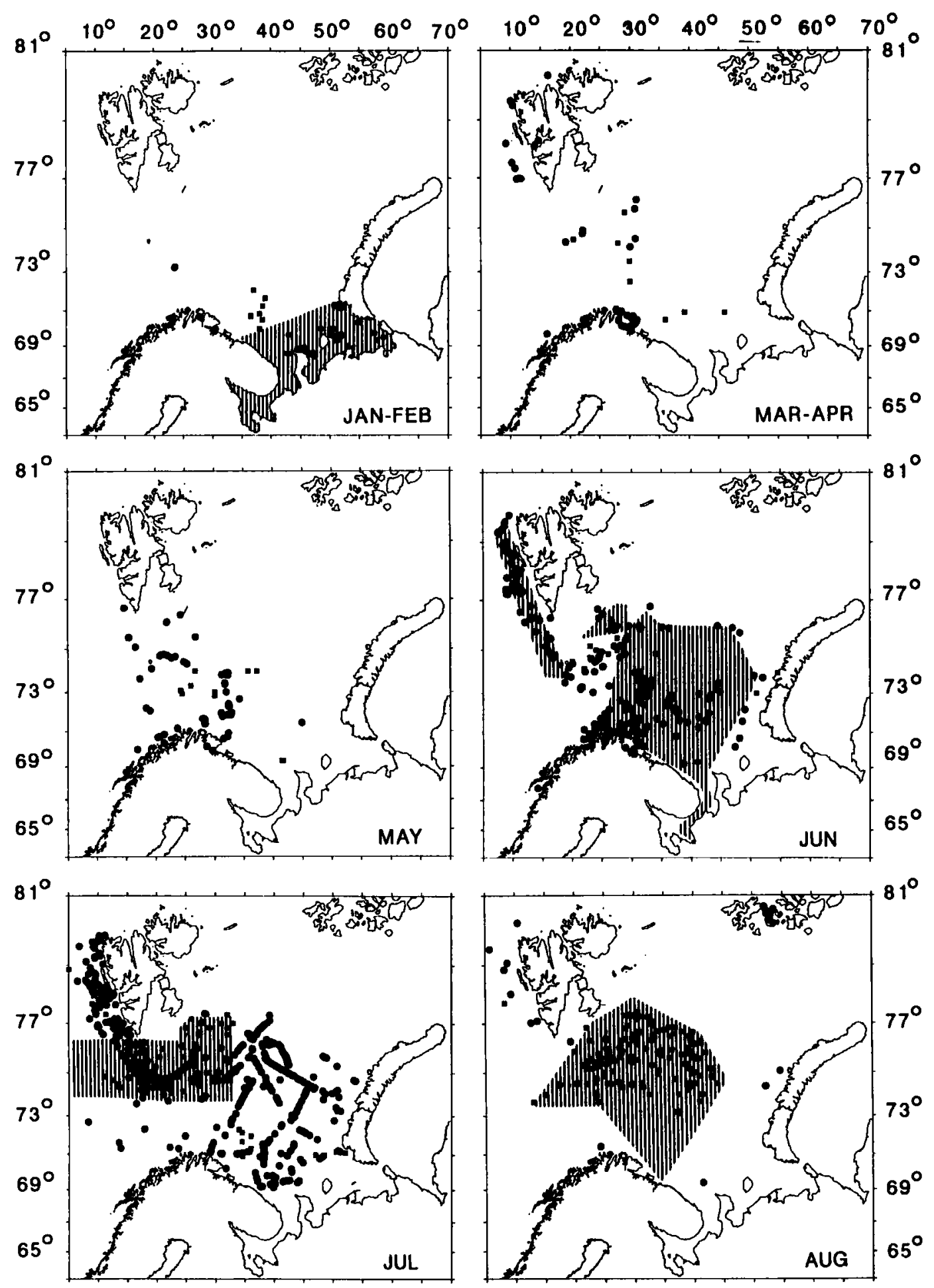

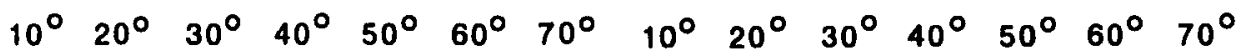



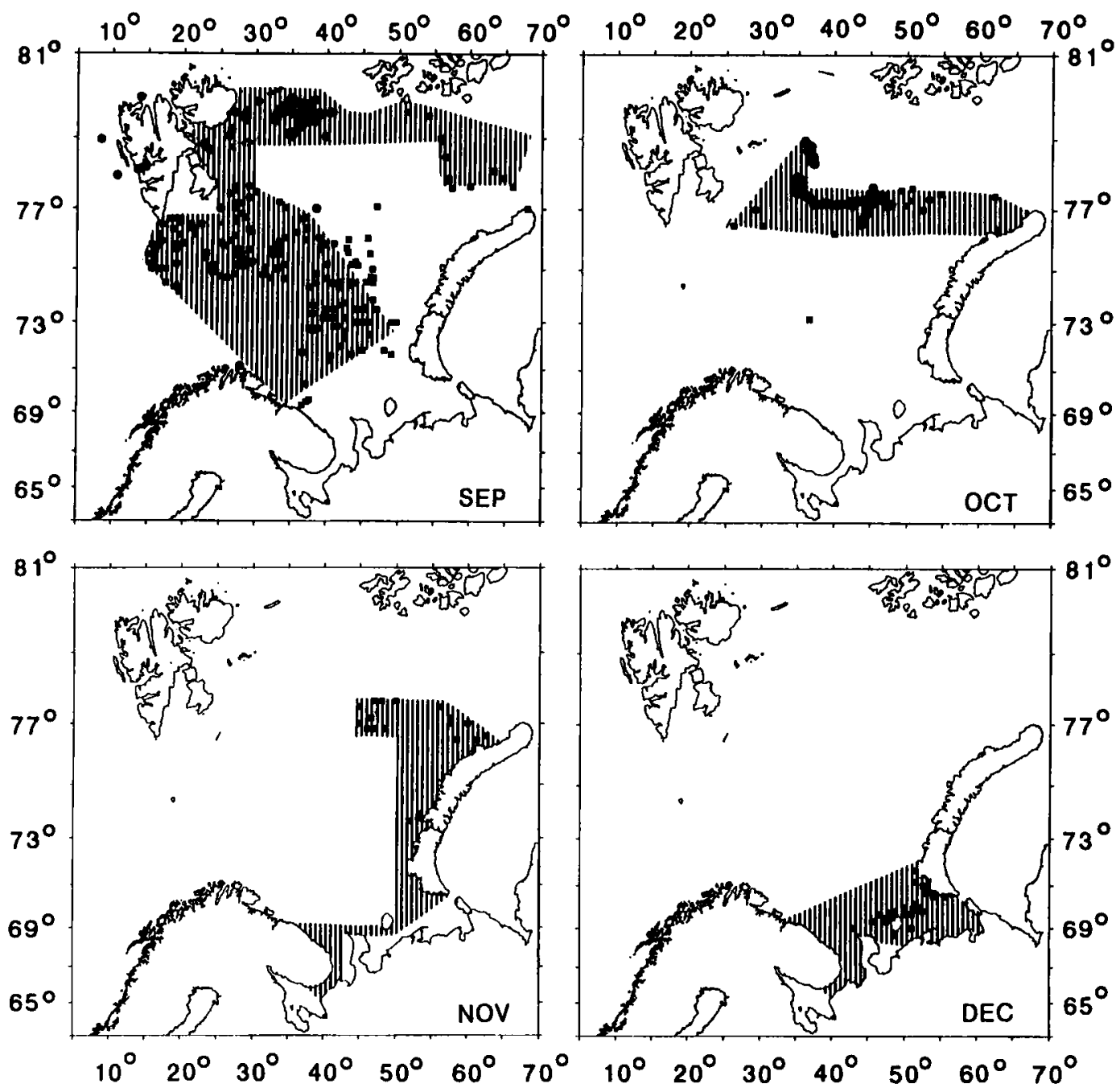

Fig. J. Norwegian (circles) and Russian (squares) sightings of harp seals (singles or groups of animals) at different times of the year in the Barents Sea. Sightings data were recorded either incidentally or during special Norwegian minke whale and harp seal surveys and Russian marine mammals surveys; the shaded areas are those covered by the two latter survey types.

$79^{\circ} \mathrm{N}$ parallels between Spitsbergen and Novaja Zemlja, always confined to the ice edge (Fig. 1). The Norwegian observations are almost exclusively from a harp seal ecology investigation survey performed in October in 1992. Harp seals were then observed to migrate from approximately $79^{\circ} \mathrm{N}$ and southwards to ca. $76^{\circ} \mathrm{N}$ within a period of two weeks due to low temperatures which caused the ice cover to move rapidly southwards. Russian surveys performed using planes and research vessels in 1987 confirm an easternly distribution of harp seals along the ice edge.

\section{November}

During the first week of November 1987, Russian research vessel surveys observed most harp seals to be confined to the fringe of the pack ice between $45^{\circ} \mathrm{E}$ and the northwest coast of Novaja Zemlja (Fig. 1). Some seals were also observed 
further south along the western coast of Novaja Zemlja, while no seals were observed along the southwest coast of this island, in the southeastern Barents Sea or along the Kola coast (Fig. 1).

\section{December}

Russian ship board surveys in December 1960 and 1965 revealed harp seals confined to pack ice in the areas between the southern coast of Novaja Zemlja and Cape Kanin (in the Pechora Sea) (Fig. 1).

\section{Discussion}

\section{January-February}

The presented observations of harp seals in the southeastern Barents Sea in this period are consistent with previous knowledge that by the end of January and in early February the majority of mature seals, first the females and somewhat later the males, will habitually move south towards and into the White Sea to prepare for the breeding season which includes whelping (c. 20 February to 5 March) and ca. 12 days lactation (Iversen 1927; Sivertsen 1941). In winter the north and northeastern parts of the Barents Sea are usually covered with dense pack ice (Loeng 1989), which makes occurrence of harp seals in these areas rather unlikely. In January and February the majority of Barents Sea harp seals seems to be concentrated near the southern end of their range, including the areas southwest of Novaja Zemlja, the northern White Sea and Kola coast (Čapskij 1961; Popov 1970).

\section{March-April}

In early March large numbers of mature seals concentrate in the White Sea to breed (Iversen 1927; Sivertsen 1941). During lactation and for some time after weaning, females and pups will move passively with the drifting ice (Popov 1970). This drift, which is influenced by prevailing currents and winds, is usually northwards and brings the pups out into the Barents Sea in April. In some years, however, constant northerly winds in March and April may move the pack-ice southwards, bringing pups to the southern shores of the White Sea. According to Popov (1970), the passive drift of pups from the southern part of the
White Sea estuary northwards past Cape Kanin may take from 20 to 50 days, depending upon the velocity of the ice drift. This means that the pups will be present in the southeastern parts of the Barents Sea during the first half of April which is also the time they are assumed to start independent feeding (Sivertsen 1941).

After the breeding period, ending with mating ca. two weeks after whelping (Iversen 1927; Sivertsen 1941), an emigration from the White Sea and subsequent feeding migration westwards along the Kola coast to Varangerfjord in North Norway of the mature females is known to occur (Nilssen et al. in press). The present observations from Varangerfjord are consistent with such a migrational pattern.

Our observations (Fig. 1) from the northern areas indicate that harp seals may also occur quite far from the southern coastal areas of the Barents Sea in March-April. Throughout April, however, most seals are presumed to migrate towards the moulting lairs inside and outside the White Sea mouth. In these areas, all age groups of the population are known to be gathered by the end of April (Nazarenko \& Timoshenko 1974; Benjaminsen 1979; Kjellqwist et al. in press).

\section{May}

In early May harp seals occur in their moulting areas both inside and outside the White Sea mouth (Čapskij 1961; Nilssen et al. in press). During May, however, the seals seem to start moving north and northwestwards into the Barents Sea, a migration which leaves virtually no animals south of Cape Kanin after 15 May (Sivertsen 1941). The immediate stimulus of the animals to go northwards is assumed to be the disappearance of ice from the White Sea (Čapskij 1961). During and after completed moult, the seals seem to follow the receding ice edge, retiring gradually northwards in the Barents Sea and possibly, at least to some extent, also into the Kara Sea (Smirnov 1924; Čapskij 1938, 1961; Wiig 1988). Smirnov (1924) emphasised that some seals may remain at Finnmark and Kola coasts in spring before they leave for open waters. The presented observations from May confirm this view.

\section{June-July}

The summer distribution of harp seals will change almost continuously in relation to changes in the 
configuration and location of the drifting pack ice. From compiled statistics of catches, Capskij $(1938,1961)$ reported that in June, harp seals (some of them still moulting) were both found off the southwestern coast of Novaja Zemlja and along the ice edge in the central parts of the Barents Sea southeast of Hopen Island but west of ca. $40^{\circ} \mathrm{E}$ as also seen in our material. Observations of harp seals in drift ice waters southeast of Hopen were also made in June 1973 by Christensen (1974).

During whale surveys in July 1974 and 1975 (Benjaminsen et al. 1976), large numbers of harp seals were observed off the west coast of Novaja Zemlja as well as southeast of Hopen and west of Spitsbergen. This is consistent with our findings (Fig. 1). It has been hypothesized that harp seals from the Barents Sea and from the Greenland Sea intermix during summer in waters off Svalbard (see Sivertsen 1941). Such feeding ground mixing between these two breeding populations is confirmed also from more recent tagging experiments (Øien \& Øritsland 1991). It is impossible, based only on observations, to ascertain whether the harp seals observed west of Spitsbergen in the present material belong to the Greenland Sea or the Barents Sea populations, or both.

\section{August-September}

Observations of harp seals in the Franz Josef Land archipelago, off the northernmost coasts of Novaja Zemlja, and in the northern Kara Sea were made in August-September 1979 (J. Nazarenko, SevPINRO, Arkhangel'sk, Russia, pers. comm.). These, and the observations presented here (Fig. 1) are consistent with previous assumptions, stating that in August and September the harp seals disperse along almost the entire ice edge from Spitsbergen to the northeastern parts of the Kara Sea including part of the Franz Josef Land (Čapskij 1961). Interestingly, despite considerable sighting effort in the areas in August, only a few harp seals were seen along the southern coasts of the Barents Sea and over the continental shelf along the west coast of Spitsbergen (Fig. 1). The latter could indicate that the Greenland Sea and the Barents Sea stocks have started to move westwards and eastwards, respectively, at this time of the year. Certainly, the ice was distributed further south in the Barents Sea in September in 1981 and 1983 than in 1990 and 1991. Our data, thus, support the view that the late summer and early autumn distribution of harp seals in the Barents Sea will change in relation to changes in the configuration and location of the borders of the drifting ice (see Capskij 1961).

\section{October-November}

The observed trend of a northeastward migration of harp seals in August is even stronger in October when our observations are consistent with previous assumptions that the harp seals start to move eastwards along the fringe of the pack ice towards Novaja Zemlja in October-November (Čapskij 1961). However, the exact time and patterns of migration from the feeding areas in the northern parts of the Barents Sea towards the White Sea are not known in detail. The presented data confirm the presence of seals along the ice fringes in the north as late as in early November, but also with some animals apparently on their way southwards. The southward migration route of the animals is assumed to be very close to the western coast of Novaja Zemlja (Čapskij 1961). Capskij (1961) suggested that the herds of harp seals, which during fall and winter comprise mixed schools of mature and immature males and females, move to southern Novaja Zemlja in the beginning of October and usually remain along the southwestern coast of the island during late fall and early winter. The presented observation data set may indicate that this southward migration takes place somewhat later (November). Since the movement of the population to the southern parts of the Barents Sea takes place before the advance of the ice edge, it has been suggested that the migrational mechanism at this time of the year is of a trophic character where the seals move southwards to search for food (Čapskij 1961).

\section{December}

The December observations clearly resemble those from January-February. Čapskij (1961) suggested that in some years harp seals might also occur in the White Sea and along the Kola coast from November on, depending on variable weather, ice conditions, and food availability. The annual winter occurrence of harp seals in Norwegian coastal waters (Nilssen et al. in press) suggests that a more westerly early winter distribution may have been common in recent years. 


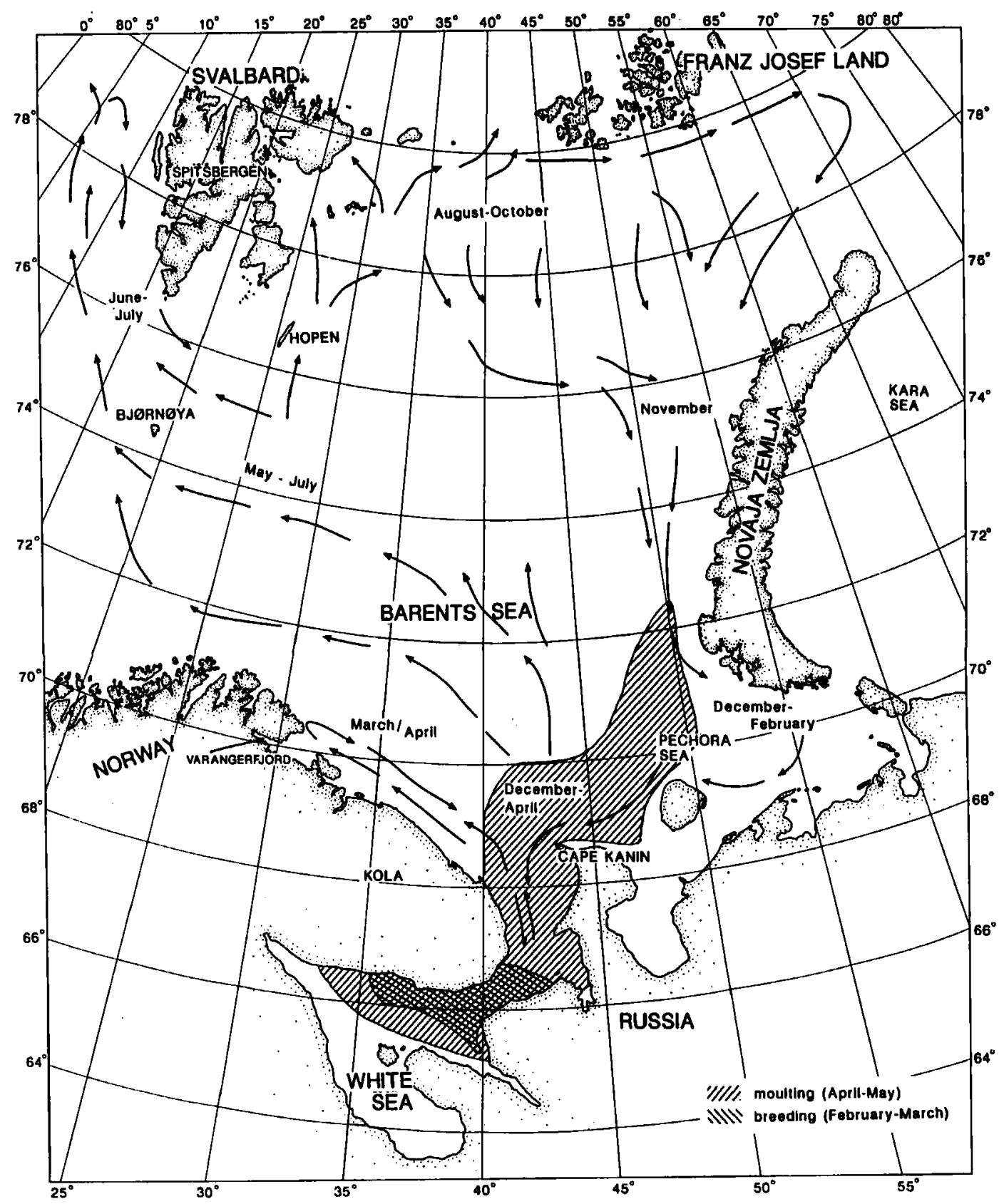

Fig. 2. Annual migrational patterns of the Barents Sea harp seals. The extensions of the breeding and moulding areas are indicated.

The annual migrational patterns

The apparent annual migrational route of the Barents Sea harp seals is summarised in Fig. 2. In winter and spring (December-May), the stock seems to be concentrated at the southern end of its range, primarily in the southeastern parts of the Barents Sea and in the White Sea where breeding and moult occur (Čapskij 1961; Nazarenko \& Timoshenko 1974; Benjaminsen 1979; Kjellqwist et al. in press; Nilssen et al. in press). Between breeding and moult, a feeding migration 
of mature females from the White Sea and westwards along the Kola coast, at least to Varangerfjord in North Norway, seems to occur in March-April (see Nilssen et al. in press).

In May, during and after completed moult, the seals start to migrate north and northwestwards in the Barents Sea. From June the seals are distributed both in open waters in the central and southern parts of the Barents Sea and in pack-ice waters from Novaja Zemlja in the east, along the pack-ice belt to the north and along the western coast of Spitsbergen. In August, a northeastward migration of the animals appears to occur in that they seem to disappear both from the western coast of Spitsbergen and from the central and southern parts of the Barents Sea.

This north and eastwards trend in migration and distribution of the seals is even more apparent in October and November. Both the distribution and feeding of the harp seals during the autumn (September-October) seem to depend very much of the location of the pack-ice edge when the seals follow the receding ice edge, retiring gradually northwards and eastwards in the Barents Sea (Nilssen et al. 1991, 1992).

The exact time and patterns of the late autumn migration from the northern parts of the Barents Sea towards the southern areas are not known. Our observations confirm that the migration takes place before the southward advance of the drifting pack ice, probably during November. In December the harp seals appear to have moved southwards where they were observed between the southwestern coast of Novaja Zemlja and Cape Kanin.

Acknowledgements. - Thanks are due to $\mathrm{S}$. Hartvedt and $\mathrm{F}$. Strand for technical assistance, to B. Gulliksen for comments on the manuscript. and to R. T. Barrett for language correction. The harp seals investigations were funded by the Norwegian Council of Research, project no. 4001-2800.083. Punching and verification of Russian data were funded through AKUP project no. 73 (Det Kongelige nærings- og energidepartement).

\section{References}

Anon. 1992. Report on the Joint ICES/NAFO Working Group on Harp and Hooded Seals, Copenhagen, 14-18 October 1991. ICES CM 1992/Assess:5. 41 pp.

Anon. 1994. Report of the Joint ICES/NAFO Working Group on Harp and Hooded Seals, Copenhagen, 15-21 September 1993. ICES CM 1994/Assess:5. 35 pp.

Benjaminsen, T. 1979. Pup production and sustainable yield of White Sea harp seals. Fisk.dir. Skr. Ser. Hav.unders. 16 , 551-559.

Benjaminsen, T., Berlund, J., Christensen, D., Christensen,
I., Huse, I. \& Sandnes, O. 1976. Merking, observasjoner og adferdsstudier av hval i Barentshavet og ved Svalbard i 1974 og 1975. Fisken Hav 76(2), 9-23.

Bogstad, B. \& Tjelmeland, S. 1990. Estimation of predation mortality of capelin using a cod-capelin model for the Barents Sea. ICES CM 1990/H:16. 32 pp.

Capskij, K. K. 1938. Novejšhie dannye o raspredelenii Belmorskoj rasy Grenlandskogo tjulenja vne Belmorskogo bassejna (New data on distribution of the White Sea race of harp seals outside the White Sea basin). Problemy Arktiki 4, 105-131.

Čapsij, K. K. 1961 (1962). Nektorye ékologiceskie obosnovaniia sezonnoj dynamiki areala belomorskoj populjatsii grenlandskogo tjulerja (Pagophoca groenlandica) (Some biological factors determining seasonal changes in distribution of the White Sea harp seals population (Pagophoca groenlandica)). Trudy Soveščanija. Ichtiol. Komissii Akad. Nauk. SSSR 12. 150-163 (Transl. Ser. Fish. Res. Bd Canada 380. 1-22).

Christensen, I. 1974. Undersøkelser av vågehval i Barentshavet og ved Øst- og Vestgrønland i 1973. Fiskets Gang 60, 278286.

Haug, T. 1993. Studies of minke whale (Balaenoptera acutorostrata) ecology in the Northeast Atlantic: Description of the Norwegian 1992 scientific catch activities. Int. Whal. Comm. SC/45/NA2. $26 \mathrm{pp}$.

Haug, T., Krøyer, A. B., Nilssen, K. T., Ugland, K. I. \& Aspholm, P. E. 1991 Harp seal (Phoca groenlandica) invasions in Norwegian coastal waters: age composition and feeding habits. ICES J. Mar. Sci. 48, 363-371.

Haug, T., Lindstrøm, U., Nilssen, K. T. \& Røttingen. I. 1994. Studies of minke whale (Balaenoptera acutorostrata) ecology in the northeast Atlantic: Description of the 1993 scientific catch operations and preliminary results from stomach analyses and resource surveys. ICES CM 1994/N:14. 53 pp.

Haug, T., Gjøsæther, H., Lindstrøm, U. \& Nilssen, K. T. in press: Diets and food availability for northeast Atlantic minke whales (Balaenoptera acutorostrata) during summer in 1992. ICES J. Mar. Sci.

Iversen, T. 1927. Drivis og selfangst. Årsber. vedk. Norg. Fisk. 1927(2). 1-84.

Jakovenko, M. J. 1967 (1969). Belmorskaja populjarsija grenlandskogo tulenja i perspektivy ee èkspluatacii (The White Sea population of harp seals and the prospects of its exploitation). Trudy PINRO (Proceedings of Polar Research Institute of Marine Fisheries and Oceanography) 21. 19-26 (Transl. Ser. Fish. Res. Bd. Canada 1321, 1-35).

Kjellqwist, S. A., Haug, T. \& Øritsland, T. in press. Trends in age composition, growth and reproductive parameters of Barents Sea harp seals. Phoca groenlandica. ICES J. Mar. Sci.

Loeng, H. 1989. Ecological features of the Barents Sea. Pp. 327-365 in: Rey, L. \& Alexander, V. (eds.) Proceedings of the sixth conference of the Comite Arctique International 1315 May 1985. E. J. Brill, Leiden.

Meisfjord, J. \& Nævdal, G. in press. Using isoelectric focusing to discern enzyme variation in Northeast Atlantic stocks of harp seals. Hereditas.

Nazarenko, Y. I. \& Timoshenko, Y. K. 1974. Age structure and sex ratio in the White Sea population of Pagophoca groenlandica as an index of efficiency of protective measures. Zoologicheskii Zhurnal. 53(2), 256-262.

Nilssen, K. T., Haug, T. \& Potelov, V. 1991. Field studies of harp seals (Phoca groenlandica) distribution and feeding ecology in the Barents Sea in September 1990. ICES CM $1991 / N: 3.23$ pp. 


\section{T. Haug et al.}

Nilssen, K. T., Haug, T., Potelov, V. \& Timoshenko, Y. K. 1992. Preliminary data on feeding and condition of Barents Sea harp seals (Phoca groenlandica) throughout the year. ICES CM 1992/N:5. 23 pp.

Nilssen, K. T., Ahlquist, I., Eliassen, J-E., Haug, T. \& Lindblom, L. 1994. Studies of food availability and diet of harp seals (Phoca groenlandica) in the southeastern Barents Sea in February 1993. ICES CM 1994/N:12. 24 pp.

Nitssen, K. T., Haug. T., Potelov, V., Stasenkov, V. \& Timoshenko, Y. K. in press. Food habits of harp seals (Phoca groenlandica) during lactation and moult in March-May in the southern Barents Sea and White Sea. ICES J. Mar. Sci.

Øien, N. 1989. Sighting estimates of Northeast Atlantic minke whale abundance from the Norwegian shipboard surveys in July 1987. Rep. Int. Whal. Comm. 39, 417-421.

Øien, N. 1990. Sighting surveys in the Northeast Atlantic in July 1988: distribution and abundance of cetaceans. Rep. Int. Whal. Comm. 40, 499-511.

Øien, N. 1991. Abundance of the northeast Atlantic stock of minke whales based on shipboard surveys conducted in July 1989. Rep. Int. Whal. Comm. 41, 433-437.
Øien, N. \& Øritsland, T. 1991. Resources of harp seals (Phoca groenlandica) tagged as pups in the Greenland Sea: pup production and dispersion patterns. Joint ICES/NAFO Working Group on Harp and Hooded Seals, Copenhagen, 14-18 October 1991. WP SEA-33. 21 pp.

Popov, L. A. 1970. Soviet tagging of harp and hooded seals in the North Atlantic. Fisk.dir. Skr. Ser. Hav.unders. 16, 1-9.

Sergeant, D. E. 1991. Harp seals, man and ice. Can. Spec. Publ. Fish. Aquat. Sci. 114. 153 pp.

Sivertsen, E. 1941. On the biology of the harp seals Phoca groenlandica Erxl. Investigations carried out in the White Sea 1925-1937. Hualrddets Skr. 26. $166 \mathrm{pp}, 10 \mathrm{pl}$.

Smirnov, N. 1924. On the eastern harp seals Phoca (pagophoca) groenlandica var. oceanica Lepechin. Tromsø Mus. Ärsh. 47(2), 1-11.

Wiig, $\emptyset$. 1988. Grønlandssel og selinvasjon. Hva vet vi - hva tror vi? Naturen 1988 (2), 35-41.

Wollebak, A. 1907. Über die Biologie der Seehunde und die Seehundjagd in europäischen Eismeer. Rapp. p.-v. Réun. Cons. Int. Explor. Mer 8, 5-82. 